\title{
Study Day of Electrocardiogram
}

National Cancer Institute

\section{Source}

National Cancer Institute. Study Day of Electrocardiogram. NCI Thesaurus. Code C83257.

The day of the week for an electrocardiogram. 